\title{
棚田畦畔の草刈り管理がコモリグモ類の個体数の動態に 及ぼす影響
}

\author{
静岡県菊川市倉沢地区の「千框の棚田」の調查事例 \\ Effect of mowing ridges on the population density of wolf spiders in rice terraces \\ A study of the rice terraces of Kurasawa district, Kikugawa, Shizuoka
}

稲垣 栄洋* 松野和夫* 大石智広* 高橋智紀*

Hidehiro Inagaki* Kazuo Matsuno* Tomohiro Ohishi* Tomoki Takahashi ${ }^{*}$

(*静岡県農林技術研究所)

(*Shizuoka Prefectural Research Institute of Agriculture and Forestry)

\section{I はじめに}

農薬に過度に依存しないIPM（総合的害虫管理）を進 める上で，害虫を捕食したり，害虫に奇生する土着天敵 のはたらきが注目されている。欧州では，土着天敵など の農業に有用な生物多様性は持続的な農業を実現するた めの重要な資源の一つと認識されおり，農地の周囲のへ ッジロウやフィールドマージンなどの緑地帯によって生 物多様性を保全するとともに，上着天敵の密度を高める 試みが行われている1)。また，これらの管理は，環境直 接支払いのために取り組むべきオプションともなってい る。

一方, 日本では, 欧州のように農地周边の環境を活用 して，土着天敵を増加させることは積極的には行われて こなかった。しかしながら，2007年に農林水産省生物多 様性戦略が策定され ${ }^{2)}$ ，農業環境における生物多様性が 着目される中で，土着天敵など農業に有用な生物の保全 が重要視されつつある。

水田のコモリグモ類は，水田にもっとも普通に見られ る代表的な俳徊性のクモであり，広食性の捕食者である ことから, 水稲害虫の捕食性天敵としての役割が期待さ れる。水田内のコモリグモ類の個体群は, 耕起・代かき の方法や農薬散布の影響を受けて減少し, 水田の外から の侵入した個体によって形成されることが明らかとなっ ている ${ }^{3)}$ 。そのため, 水田内のコモリグモの個体数を維 持するためには不耕起栽培や，無農薬栽培が有効である 4,5,6)。しかしながら，不耕起や無農薬栽培を行うために は，稲の栽培体系を大きく改変しなければならない。
一方，日本では，欧州に見られる農地周囲の緑地帯の 管理のような特別な生物多様性保全は行われていないも のの, 水田はもともと, 湛水するために畦畔が形成され ており, 草刈り等の管理によって植物が自生する草地環 境が保たれている。慣行農法において，耕起や農薬散布 によって減少した個体群が水田外部からの供給によって 維持されているとすれば, 水田周囲の畦畔をコモリグモ の供給源として機能していることも考えられる。また， さらには畦畔の管理手法によって，コモリグモ類を保全 したり，增殖できることが示唆される。しかしながら， 畦畔管理とコモリグモの個体数との関係については明ら かとなっていない。

そこで本研究は, 水田面積に対して畦畔面積が広いこ とから畦畔の機能を評価しやすく，さらに，多くの管理 者によって管理され，管理者によって畦畔管理方法が異 なる棚田の特徴に着目し，棚田における畦畔植生の違い や，草视り管理の違いがコモリグモの個体数に及ぼす影 響について調查を行った。

一方，欧州では，農地周辺の緑地帯の草刈り時期をず らしたり、一部を刈り残すことによって, 土着天敵を含 めた生物種の生息場所の保全を行っている ${ }^{6)}$ 。れに対 して，日本で行われる刈払い機による草刚りは，植物を 除去するにとどまらず，露出した土壤を削りながら行わ れることも少なくない。このような過度の草刚り圧は， 畦畔に生息するコモリグモに大きな影響を与えているこ とが懸念される。そこで, 草刚りの高さを地際でなく, 一定の高さで行うことによって，擋乱を减少しコモリグ モの個体数を増加できるのではないかと仮説し，試験的 


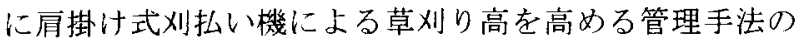
効果についても検証を行った。

\section{III調查地と調查方法}

\section{1. 調查地の概要}

静岡県菊川市倉沢地区の「千框の棚田」を調査地とし た（図 1)。菊川市は静岡県の中西部地域に位置する中都 市である。倉沢地区は菊川市北東部に位置し，大井川下 流右岸の洪積台地である牧之原台地と小笠山丘陵にはさ まれた低平地を流れる菊川流域にある。調查地の棚田は， 牧之原台地西斜面のすり鉢状の地形の中に残る畑-水田 地形連鎖系の棚田であり，標高 $80 \mathrm{~m} \sim 140 \mathrm{~m}$ の範囲に広 がっている。地滑り地帯に拓かれた棚田は石垣を用いず, 土披によって畦畔が形成されている。棚田枚数は 188 枚 であり, 棚田面積 $1.5 \mathrm{ha} の う ち$ 畦畔面積が 0.7ha を占めて いる。棚田の管理は地域の棚田保全推進委員会と 4 戸の 農家とがそれぞれ行っている。4 戸の農家によって管理 されているエリア（以下，農家管理エリア）は，草刘り 時期は農家によって異なるが，同じ農業者によって管理 されている水田は，比較的植生が均一であることで特徽 づけられる。一方，棚田保全推進委員会によって管理さ れるエリア（以下，保全エリア）は，草刈り日等は統一 されているが，棚田オーナ一やボランティアなど，さま ざまな参加者によって草刈りが行われることから，畦畔 によってさまざまな植生が見られる点で特徴づけられる。

農家管理エリア，保全エリアともに，田植えは 5 月下 旬から 6 月上旬に行われる。畦畔管理は肩掛け式刈払い 機によって行われており，畦畔への除草㓮の散布は行わ れていない。また, 保全エリアは本田への殺虫剤, 除草 剂ともに散布は行われていないのに対し，農家管理エリ アは，エチプロー・シラフルオフェン水和剂（商品名： キラップジョーカーフロアブル)の散布が行われている。

\section{2. 調查方法}

(1)棚田畦畔の俳徊性クモ相

コモリグモ類の種の同定は顕微鏡下での生殖器の観察 が必要であり，野外では種の判別が困難である。そのた め, ピットホールトラップで捕獲したコモリグモ類の種 組成を調査した。

調查は, 2008 年 5 月 21 日に径 $10 \mathrm{~cm} の$ ピットホールト ラップを 6 カ所に設置した。ピットホールトラップの設 置位置は図 1 のとおりである。ピットホールトラップに は餌や誘引剤は使用しなかった。2 週間後の 2008 年 6 月 4 日にトラップを回収し，トラップ内に捕獲された俳徊 性クモ類を $70 \%$ エタノールによって固定した後，顕微鏡 下で種を同定した。

\section{(2)哇畔植生がコモリグモ類の個体数に及ぼす影響}

草刈り時期が同一である保全エリアを 6 つのブロッ クに分けて, 各ブロックから 4 本の畦畔を無作為に抽出 し, 計 24 本の畦畔を対象に, 畦畔の植生とコモリグモ 類の個体数の調査を行った。調査は 2007 年 9 月 4 日に 行い, 畦畔 1 本当たり, 畦畔を 5 等分した地点の両端を 除いた中の 3 点を対象に $0.5 \mathrm{~m} \times 1 \mathrm{~m}$ のコドラートを設置 し，コドラート内のコモリグモ類の個体数を見取りで計 測した。コモリグモ類の個体数の調査は, 午前 9 時 30 分から 11 時 30 分の時間帯で行った。

また，コドラートごとに被度 $5 \%$ 以上の出現草種につ いて，草高と被度を測定して積算優占度 $\left(\mathrm{SDR}_{2}\right)$ を算出し， 各植物種の積算優占度を PC-ORD (MjM Software Design, Oregon, U.S.A) を用いて TWINSPAN (Two-way Indicator Species Analysis) 解析による類型化を行った。 TWINSPAN は類型化された筆数が 3 筆以上となるよう に行った。なお，調査対象とした範囲は 2007 年 7 月 8 日，8月 5 日に草刈りが行われている。

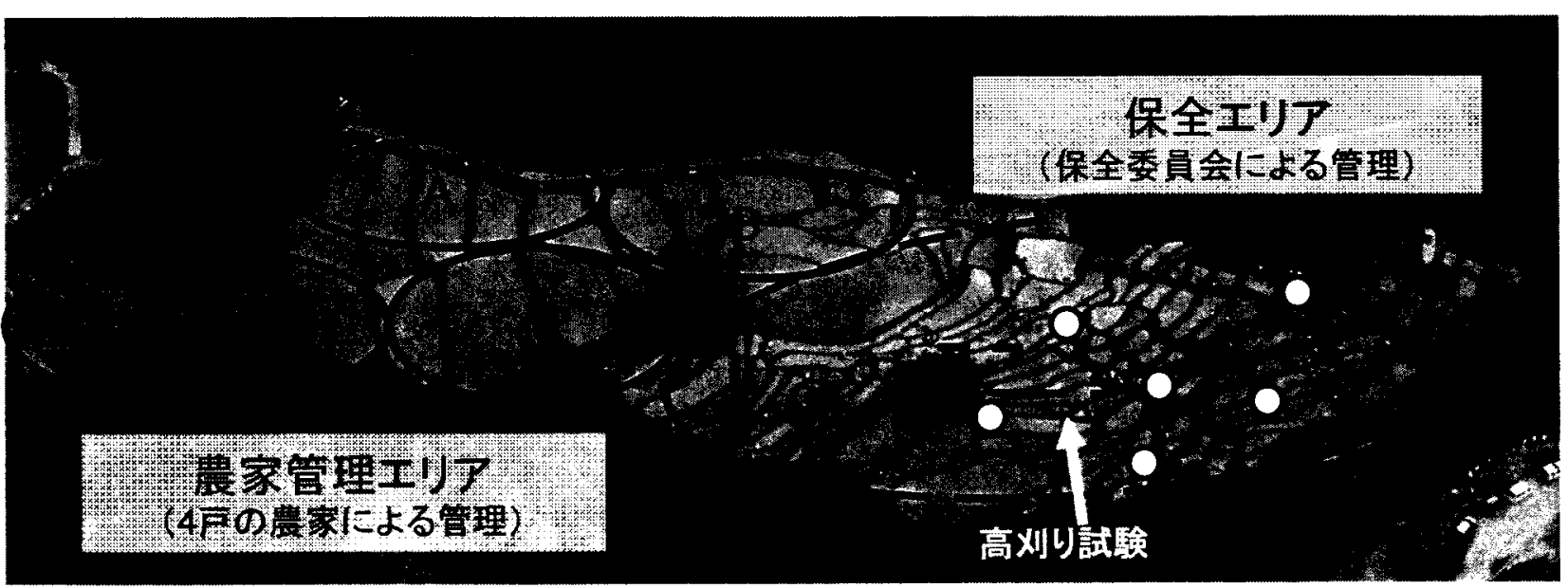

図 1 調査地の概要（○：ピットホールトラップ設置位置）

Fig. 1 Outline of study area. ( 0 : position of pitfall traps) 
表 1 記録された徘徊性クモ類の種名と個体数

Table 1 Number of individuals of wandering spiders sppcies recorded.

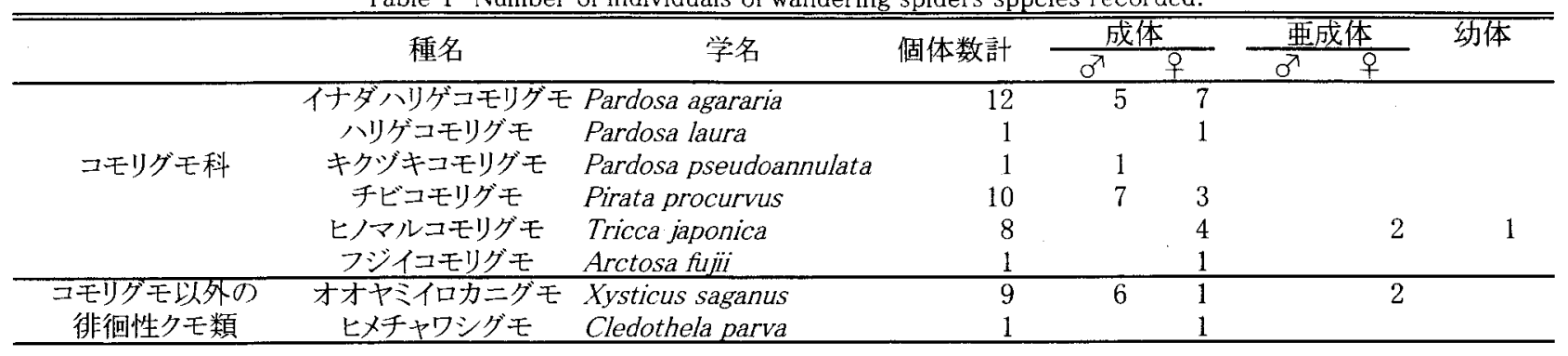

(3)畴畔の草刈り時期がコモリグモ類の個体数に及ぼす

\section{影䈉}

農家エリアの 4 戸の農家（A,B,C,D）の棚田の南北方 向のす心゙ての畦畔 13 本を対象に, 畦畔 1 本当たり, 畦 畔を 5 等分した地点の両端を除いた中の 3 点を対象に $0.5 \mathrm{~m} \times 1 \mathrm{~m}$ のコドラートを 3 カ所ずつ設置し, 2007 年 8 月 7 日から 2 週間ごとに 9 月 4 日までコドラート内のコ モリグモ類の個体数を見取りで計測した。調査は午前 9 時 30 分から 11 時 30 分の時間帯で調查を行った。

なお，各農家による草刚りは，肩掛け式刚払い機によ ってそれぞれに行われている。

(4)草刈りの高さがコモリグモ類の個体数に及ぼす影響

保全エリアの棚田畦畔のうち4月時の植生が比較的均 一である5本の畦畔を対象とした（図 1 ）。調査区は，肩 掛け式刈払い機を用いた草刈りの高さを $20 \mathrm{~cm} の$ 位置で 高到りした高刘り区と，慣行により地際で草刈りを行う 慣行区を設定した。草刈り時期は，現地慣行に合わせて 2008 年 7 月 13 日，8月 10 日，9月7日の 3 回とした。 調査は， 1 試験区当たり $0.5 \mathrm{~m} \times 1 \mathrm{~m}$ のコドラートを 3 力
所ずつ設置し, 田植え後の 2008 年 6 月 3 日から稲刈り前 の 10 月 1 日まで, 2 週間ごとにコモリグモ類の個体数と 群落高を調査した。コモリグモ類の個体数の調查は, 午 前 9 時 30 分から 11 時 30 分の時間帯で見取り調查で行っ た。また，それぞれの草刈り前の7月30日，8月27日， 10 月 7 日には前畦と畦の法面側について出現草種の草高 と被度を計測し, 植物種ごとの積算優占度 $\left(\mathrm{SDR}_{2}\right)$ を算 出した。

\section{III 結果}

\section{1. 棚田畦畔の绯徊性クモ相}

畦畔のクモ相を表 1 に示した。8 種 43 個体が記録され， うち 6 種 33 個体がコモリグモ科であった。コモリグモ類 では，特にイナダハリゲコモリグモ，チビコモリグモ， ヒノマルコモリグモの3 種の出現数が多かった。

\section{2. 畦畔植生がコモリグモ類の固体数に及ぼす影福}

TWINSPAN 解析の結果, 畦畔植生はAからFの6つ の群落タイプに類型化された（図 2 ）。TWINSPAN の第

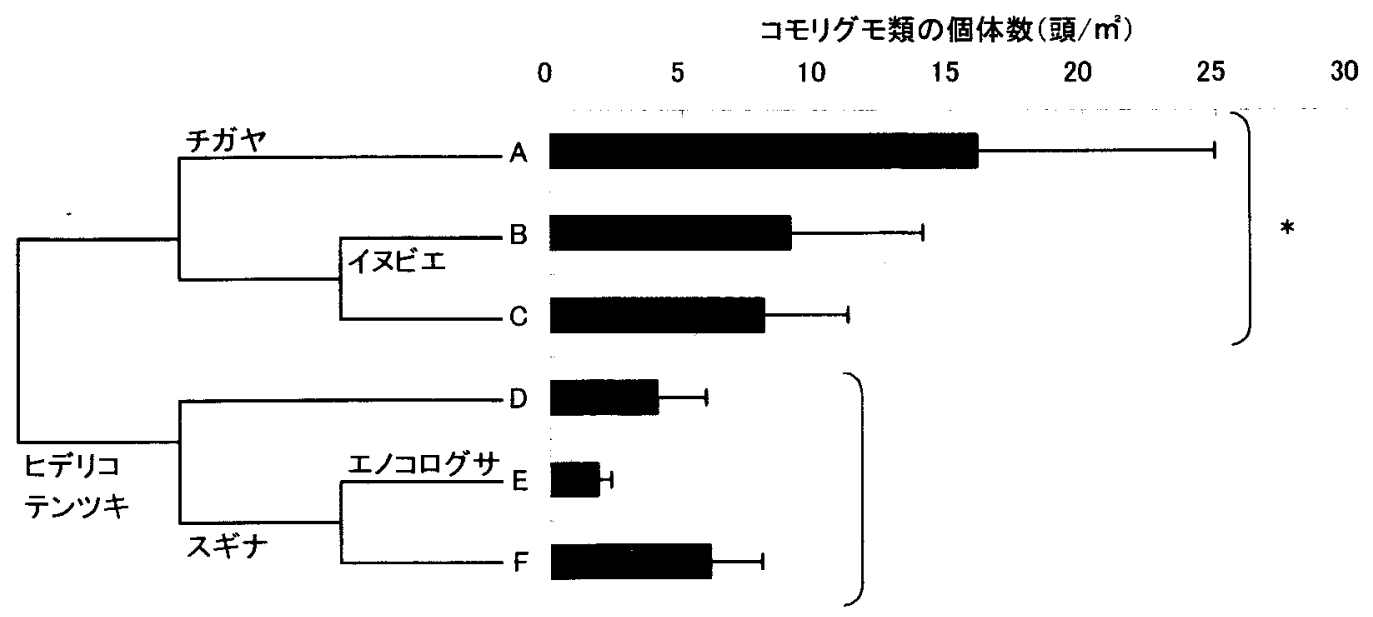

図 2 TWINSPAN による畦畔植生の類型とコモリグモ類の個体数

第 1 分割でコモりグモの個体数に $\mathrm{t}$-検定 $5 \%$ 水準で有意差あり

Fig.2 Cluster analysis of vegetation levee by TWINSPAN and individuals of wolf spiders.

* indicate significant by $\mathrm{t}$-test at $\mathrm{P}<0.05$ 
1 分割では, ヒデリコやテンツ キなど小型のカヤツリグサ科一 年生雑草の有無によって区分さ れた。第 2 分割では, ヒデリコ やテンツキがあるグループはス ギナの有無により区分され，さ らにスギナのあるグループはエ ノコログサの有無によって区分 された。一方, ヒデリコやテン ツキのないグループはチガヤの 有無によって区分され, さらに チガヤのないグループは, イヌ ビエの有無によって区分された。

群落タイプごとのコモリグモ 類の個体数は, 各グループ間の 多重検定で統計的な差異は見ら れなかったものの，第 1 分割の ヒデリコやテンツキの有無の 比較では，ヒデリコやテンツ キのあるグループで, ヒデリ コやテンツキがないグループ に比してコモリグモ類の個体 数が有意に少ない傾向が認め られた $(\mathrm{P}=0.03) 。$

\section{3. 眭鮮の草刈り時期がコモリグモ類の固体数の動態に 及ぼす影睃}

各農家における草刈り時期とコモリグモ類の個体数 の推移を図 3 に示した。8 月に草刈りを行わなかった農 家 A では,コモリグモ類の個体数は調查期間中にほとん ど增减せず，ほぼ一定で推移した。一方，8月10日に草 刈り管理を行った農家Bでは, 草刈り後の8月23日調 查時にコモリグモ類の個体数が著しく增加した。また, 9 月 1 日に草刈りを行った農家 C, 農家Dでは, 草刈り 後の 9 月 4 日調查時にコモリグモ類が増加する傾向が認 められた。農家 C, 農家Dでは調査日の9月4日は草刈 り直後であったために, 調查時において植物の再生は認 められず, コモリグモ類は草刈り後に敷き草状に放置さ れた植物残渣の下で多く観察された。

\section{4. 草刈りの高さがコモリグモ類の固体数に及ぼす影䍄}

植生調查の結果, 地際で草刚りを行った慣行区の畦畔 はメヒシバ $\left(\mathrm{SDR}_{2}=0.677\right)$, イヌビエ $\left(\mathrm{SDR}_{2}=0.512\right)$, ヒ メクグ $\left(\mathrm{SDR}_{2}=0.324\right)$ などの優占度が高い植生であった のに対し，草刘り高を $20 \mathrm{~cm}$ とした高刈り区では，コブ ナグサ $\left(\mathrm{SDR}_{2}=0.879\right)$ やハイヌメリ $\left(\mathrm{SDR}_{2}=0.670\right)$ の優
農家A(草刚なし)
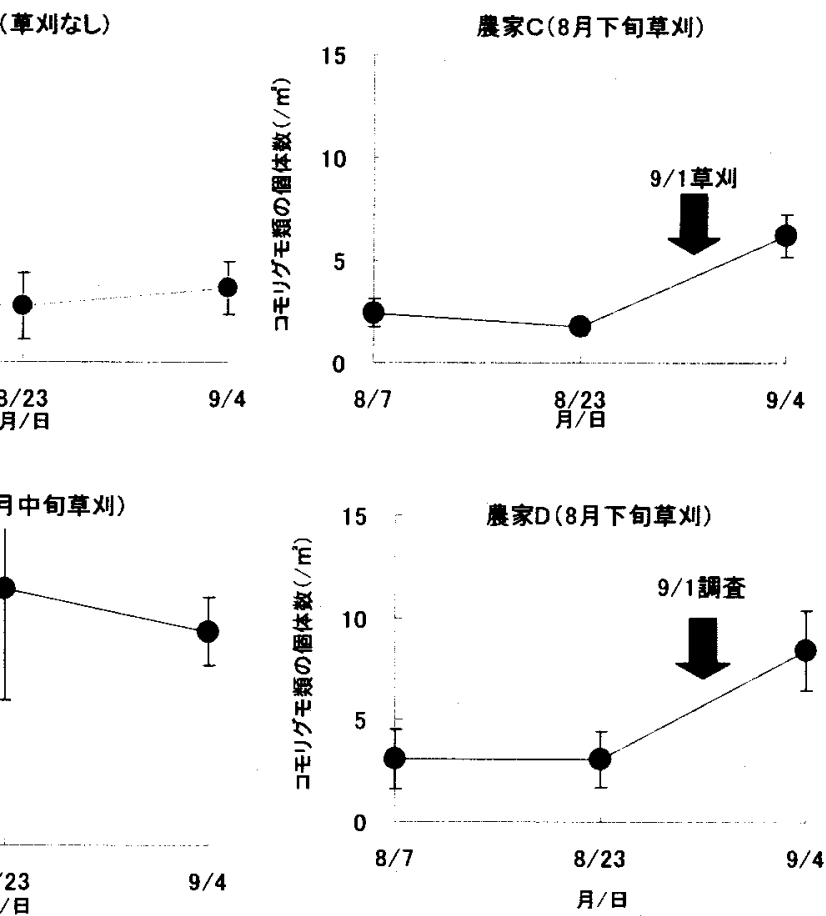

月/日

4

期の異なる水田畦畔におけるコモリグモ類の個体数の推移 エラーバーは標隻偏差

Fig. 3 Effect of the time of mowing on the number of wolf spiders in levees.

The error bars indicate standard deviation.
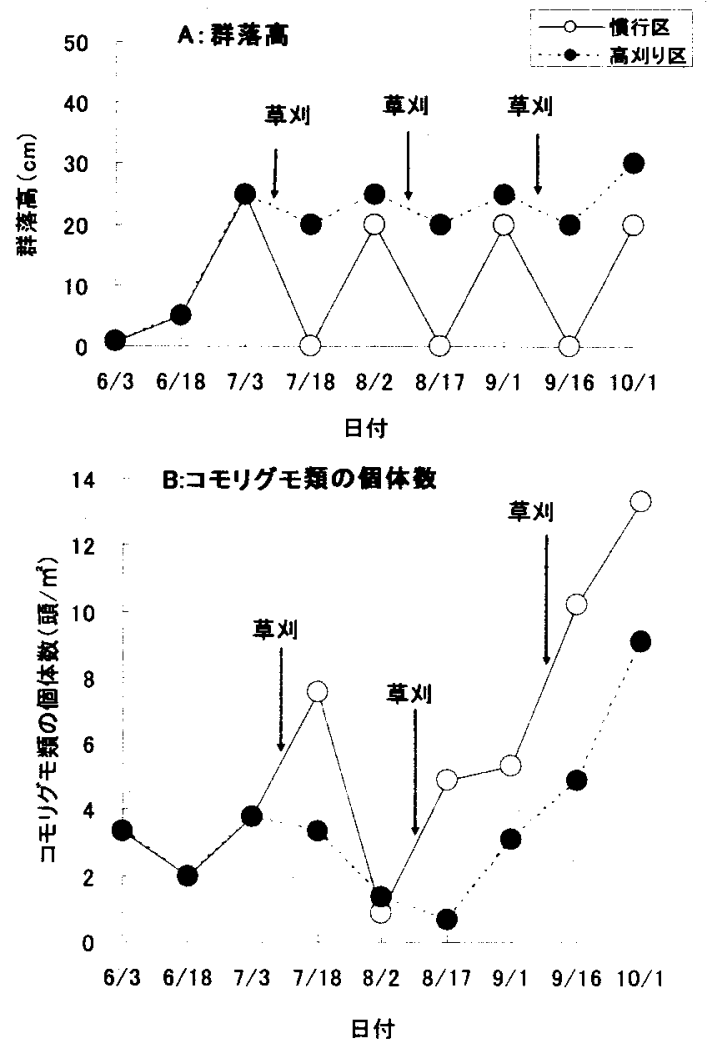

図 4 高刈り管理が畦畔の群落高さとコモりグモ類の 個体数に及ぼす影響

Fig.4 Effect of mowing at different heights on height of plant community and number of wolf spiders in levees. 
占度が高い植生が成立した。

慣行区と高刈り区における畦畔のコモリグモ類の個体 数の推移を図 4 に示した。慣行区では草刈りから次の草 刈りまでの間に群落の高さが $20 〜 25 \mathrm{~cm}$ に伸長したのに 対して, $20 \mathrm{~cm}$ の高さで草刈りを行った高刚り区では, 20 〜30 cm の範囲で群落高が推移した。

また慣行区では，草刈り後にコモリグモ類の個体数が 増加する傾向が認められた。一方，高刚り区では，7月 下旬以降減少し，8 月中旬以降增加する個体数の推移を 示した。この発生消長は, 慣行区と類似しているものの， 高刈り区では，草刚り後のクモ類の個体数の増加が見ら れず，結果としてコモリグモ類の個体数は，慣行区に比 して低く推移した。

\section{IV 考察}

\section{1.洼睷の草刈りがコモリグモに固体数に及ぼす影整}

コモリグモ類の個体数は, 草刈りの時期にかかわらず, 草刈りの直後に著しく増加する傾向が得られた（図 3 ）。 このことから，畦畔の草刈り作業はコモリグモ類の個体 群密度を高める上で有効であると考えられる。

コモリグモ類の密度に対する草刈りの影響については 採草地での調查報告があり，刈り取りによって変動しな いとする Howell らの報告 7)や刘り取後によって高まる という Jensen らの報告 ${ }^{8)}$ があるが, 棚田畦畔における本 調查の結果はJensen らと同様の傾向を示した。

畦畔の草刘りによってコモリグモが増加した要因は 明確ではない。コモリグモの個体数の増加は，草刈りの 数日後の短い期間で観察されることから，繁殖によって 增殖していることは考えにくく，周辺環境から集まって きていると推察される。また, 草刚り後は刘りとった草 を持ち出すが，すべて持ち出されることはないため，刚 られた草が畦畔に放置されて敷き草のようになる。草刚 り後のコモリグモ類の多くは，その敷き草の下で多く観 察された。このことから，敷き草の環境がコモリグモ類 の生息場所として好適環境であることが示唆される。今 後，畦畔におけるコモリグモの個体群を保全する目的で は、このような敷き草を意図的に行うことの検討も重要 であろう。しかしながら，敖き草がコモリグモの隐れ場 所として機能しているのか，あるいは敷き草環境によっ て餌動物が増加するのかについては不明である。

一方, 畦畔植生とコモリグモ類の個体数との関係では, ヒデリコやテンツキなど小型のカヤツリグサ科一年生雑 草で特徴づけられる畦畔ではコモリグモ類が比較的少な いのに対して，チガヤやイヌビエなどのイネ科雑草で特 徵づけられる畦畔では、コモリグモ類の個体数が比較的,
多い傾向が得られた（図 2)。このことから、コモリグモ 類はイネ科植生で特徴づけられる草地性の環境を好むこ とが推察される。しかしコモリグモ類がイネ科植生を嗜 好する要因については不明である。チガヤ植生は草刈り によって成立しやすいことから 9), 草刚りの結果として 成立したチガヤ植生とコモリグモ類の増加が一致した可 能性も含めて，検討をする必要がある。

\section{2.高草刚りがコモリグモの圈体数に及ほす影票}

本研究では，草刈り高を高くして，草刚りによる擋乱 程度を小さくすることによって，コモリグモの個体数を 保全できるのではないかと仮説したが，本調査からは， 高草到りの効果は認められず，むしろ高草刈りでは，慣 行で行われる地際の草刚りに比してコモリグモ類の個体 数は低く推移した（図 4)。このことから，コモリグモ類 の個体数を増加させるという観点では, 高い位置で草を 刚る手法は有効ではなく，むしろ，慣行のように地際部 で草刈りを行うことが効果的であると考えられる。しか しながら，コモリグモ類の増加は，周辺環境からの移動 によって起こることが推察されていることから，草刚り 時期をずらすことによって，草刘り作業時のコモリグモ の逃げ場所を確保する等の手法については，さらに検討 する必要があるであろう。

\section{$\mathrm{V}$ おわりに}

本調查の結果から, 棚田畦畔の草刈り作業によって, 草刈り後のコモリグモ類の個体数が増加することが明ら かとなった。これまで畦畔の草刈りは，雑草防除や斑点 米カメムシの防除という観点のみで行われてきたが, 草 刚りによって土着天敵であるコモリグモ類が増加すると いう本調査の知見は，畦畔の草刚り作業に新たな意味づ けを提供するであろう。

しかしながら，草刈りによってコモリグモが増加した 要因については不明である。ただし，草刈り後に增加し たコモリグモ類は，周辺環境から移動してきたことが示 唆されることから，今後は周辺環境も含めたコモリグモ の移動性について研究を進める必要がある。

また本調查は棚田を対象としたことから，イナダ八リ ダコモリグモやチビコモリグモを中心としたコモリグモ 類が調査の対象となった。静岡県の平坦地水田に一般に

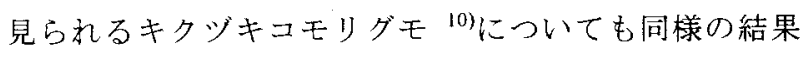
が得られるかどうか検討する必要がある。

謝辞：本研究は農林水産省交付金プロジェクト「農業に 有用な生物多様性の指標及び評価手法の開発」の研究成 
果の一部である。記して謝意を表する。また，クモ類の 同定をいただいた園田学園女子大学, 田中穂積教授に心 より深謝する。本研究を実施するにあたり，調査に協力 いただいた上倉沢棚田保全推進委員会の皆様をはじめ, 菊川市倉沢地区の皆様に厚くお礼申し上げる。

引用文献

1) Ernst, F. Boller, Frtz Hani and Hans- Micheal Poehling. Edit. (2004): Ecological infrastructures. Ideabook on functional biodiversity at the farm level. LBL.

2）農林水産省，2007，農林水産省生物多様性戦略。

3）川原幸夫・桐谷圭治・笹葉隆文・中筋房夫 ·大熊千代子 (1969) 水田に㧍けるクモの種類相と個体数の季節的消長, とくにツ マグロヨコバイの発生消長と関連して，四国植物防疫研究 $4: 33-44$.

4) Ishijima, C., T. Motobayashi, M. Nakai and Y. Kunimi. 2003. Impacts of tillage practice on hoppers and predatory wolf spiders
(Araneae: Lycosidae) in rice paddies. Appl. Entomol. Zool. 39: 155-162.

5）日鷹一雅・中筋房夫. 1990. 粗放的でも集約的でもない農法 をもとめて、10-265. 冬樹社, 東京.

6）斎藤邦行・黒田俊郎・熊野誠一２001．水稲の有機栽培に関 する継続試験。日本作物学会紀事 $70: 530-540$.

7) Howell, J. O. and R. L. Pienkowski. 1971. Spider poplation in alfalfa, with notes on spider prey and effect of harvest. J. Econ. Entomol. 64: 163-168

8) Jensen, P., G. L. Jacobson and D. E. Willard. 1973. Effect of mowing and raking on Colembola. Ecology. 54: 564-572.

9) 富永 達・西脇亜也・水口亜樹・江崎次夫. 2007. 雑草モ) グラフ 5. チガヤ (Imperata cylindrica (L.) Beauv.).雑草研 究 $52,17-27$.

10）松野和夫・稲垣栄洋 (2009)：棚田と平坦地のクモ．静岡県 農林技術研究所編. 静岡の棚田研究：27-31. 静岡新聞社, 静 岡.

Summary: In order to clarify the effect of vegetation on ridges and ridge-mowing techniques on the population density of wolf spiders, we investigated the seasonal changes in the population density of wolf spiders in rice paddy fields and in the ridges between these fields. A greater number of wolf spiders were detected in the ridges on which the Gramineae Imperata cylindrical and Echinochloa crus-galli grew than in the ridges on which the Cyperaceae Fimbrisytlis miliacea and $F$. dichotoma grew. The number of wolf spiders hardly changed from August to September in the field where the ridges were not mowed. In contrast, the number of wolf spiders increased considerably after the ridges were mowed, and these spiders were observed under the cut plants in the ridges. However, the number of wolf spiders did not increase when the ridges were mowed at a height of $20 \mathrm{~cm}$ from the ground.

(2009 年 5 月 15 日 受付)

(2009年 11 月 14 日 受理) 